IIUC STUDIES

ISSN 1813-7733

Vol.- 7, December 2010

(Published in December 2011) (p 55-62)

\title{
Illusion, Deception and Dehumanization: Neocolonial Reinforcement of Colonial Legacy and the Role of English
}

\author{
Mohammed Sarwar Alam*
}

\begin{abstract}
Under the holy mask of civilizing the world, colonizers have done the unholy task of forming and deforming societies to serve their vested interests. Over centuries, they have skillfully dominated colonized societies through illusion, deception and dehumanization. In the face of national liberation movements, they had to retreat physically, but the inhuman legacy they left behind continues to benefit them in the absence of strong resistive decolonizing discourses. Predatory globalization, through destructive development culture is now the prevailing mode of recolonization which is turning our dreams for a just global society into an ever illusive one. In this context, echoing the views expressed in "On the Abolition of the English Department" (Ngugi: 1968), this paper argues that English Language and Literature departments have been largely responsible for not forming a strong decolonizing culture and discourse. Also, this paper arrives at an understanding that like Caliban in Shakespeare, English Language now, with growing awareness across the globe, could be used to expose, curse and resist deceptions of the recolonizing forces.
\end{abstract}

Often it is argued that, in the western context, Renaissance led to Rationalism, Rationalism to Humanism and Humanism to Individualism. It is in this context that European colonialism flourished where knowledge was reduced to mere exercise of power to colonize vast tracts of lands, mostly in Africa and Asia. Whatever the prophecies of the colonizing mission, the ultimate goal of colonization has been best articulated by Michael Parenti (2006): "By imperialism,

* Assistant Professor, Dept. of English Language and Literature, IIUC 
I mean the process whereby the dominant politico-economic interests of one nation expropriate for their own enrichment the land, labor, raw materials and markets of another people." Here, in this paper my arguments rests on three interconnected points; first, to prove that colonialism, neocolonialism and globalization have the same objective of exploiting others by cultural political and economic hegemony; second, to demonstrate how English language and literature have been largely introduced (imposed) for colonial missions and its paradoxical outcomes ; third, to suggest how to contextualize the views expressed in "On the Abolition of the English Department" (Ngugi:1968), for English departments of Bangladesh .Finally I would like to conclude that learning and practicing the language "which history has forced down our throats" (Achebe, 28) could be strategically and effectively used to "generate counter discourses to resist the oppressive presence"(Alam,2007:380) of the discourses of colonialism, neocolonialism and resultant predatory corporatization or Globalization. In one of the chapters of his book, Imperial Entanglements and Literature in English, Fakrul Alam (2007:23-24) has convincingly concluded:

Baconianism then has had a decisive influence on colonial discourse from the time Bacon began to propagate his ideas about science and continued to do so for generations after his death. In fact, we could argue that the link that Bacon made between science, trade, and empire was never broken and that cognitive and political colonialism and knowledge and power went hand in hand European overseas expansion.

Almost the same conclusion is drawn by Khan when he observes "The modern imperialism was grounded on the 17th century scientific logic. Descartes had been the father of this approach.... Eventually, it led to humanism which expanded the European capitalistic imperialism" (Khan: 2009, translation mine). In the years since World War II , territorial imperialism is no longer the prevailing mode. Rather than being directly colonized by the imperial power, weaker countries have been granted the trapperings of sovereignty, although western finance capital still retains control of the lion's share of resources. This relationship has gone under various names: "Informal empire", "Colonialism without colonies", "Neocolonialism", and "Neoimperialism". 
After territorial conquests, colonizers have been concentrating on devising techniques to consolidate colonization. And education in their hands has been the most effective and powerful weapon to marginalize, uproot, inferiorize and enslave natives. This is the way which has been pointedly defined by Gramsci (2007) as "cultural hegemony". In this respect, the objective of Macaulay's education policy in colonized India is a common knowledge now. Cultural hegemony reinforces political, economic and military hegemony. Thus, imperialists determined the history of the world and changed the events of our lives. Coloniality and imperialism are relationships that have had a cultural, intellectual and social impact. The very term "post colonialism" or "neo-colonialism" suggests that legacy of colonialism still continues.

Now let us observe how neo-colonialism continues in the name of predatory globalization or corporatization based on the very logic of colonialism of the recent past. Khan sarcastically remarks, "We overstate how much we have been benefited by the subordination process of colonization, but fail to calculate how much we have been exploited because exploitation still continues". And this is deceptively defined as Development". (Khan, 1998:04)

Now in the neocolonial global paradigm, states are being systematically reduced into security apparatus leaving the fate of the peoples to the profit- maximizing forces of the market. In a marketridden entertainment-saturated world, neocolonial forces create and popularize sound-bites to confuse people and disguise newer forms of marginalization, deprivation and exploitation. These newer forms of recolonization or neo-colonization are openly supported by neocolonial propagantists like Barry Hindess (2001):

Finally, of course, the world has changed dramatically since Orwell wrote his memoir... The great liberal project of improvement, operating now under the label of development, is still pursued by Western states but it has to work through a remote set of indirect means, relying, in effect, on diplomacy, national and international aid programs that assist, advise and constrain the conduct of post-colonial states, international financial institutions and also, of course, the market. 
Through neoliberal projects of confusion and deception Neocolonization continues to be an unending hegemony. Gulliver-like corporatized Globalization is exploiting for the benefit of "a tiny and privileged minority" that enlist themselves in the club of the richest persons of the world while dispossessed and displaced number of people continue to increase more alarmingly than ever before .This neoliberal myth of development has been provocatively questioned through a set of questions by Ali Behdad (2006:) :

We may ask, for example, what functions do states, as agencies of representation, perform in the broader system of international regulation? Do global agencies and transnational corporations undermine the sovereignty of national governments? Or does the fact of their being answerable to their citizens make them the local shields against global capitalism? Can states recreate a sense of national identity in response to the political and economic constraints of globalization? Or, do state apparatuses mobilize the idea of the nation to enable the economic interests of transnational corporation? (73)

This paradigm has got revealing expression in Arundhati Roy (2009:xii): “... nationalism and development those unimpeachable twin towers of modern, Free Market Democracy (...) encrypted with the potential of bringing about ultimate apocalyptic destruction (nuclear war, climate change). Through neocolonial global economic order peripheral states are being subordinated to defend the interest of transnational corporations. In Bangladesh, it is in this paradigm that we have lost lives at Kansat, killed by patriotic (?) security forces defending the interests of the transnational corporations. And, we often see that people struggling to defend the interests of the state are being prosecuted and persecuted by the state itself.

Bangladesh is a "twice-born" country. Nevertheless, the country has been hardly able to decolonize itself. Rather, it appears that it is being further entrapped by recolonizing forces. This can only happen because of the marked absence of decolonizing praxis at all levels. And, we argue that the absence is created by the colonially wombed opportunistic parasitic educated middle class who are brainwashed by capitalistic class-biased submissive knowledge production systems. This is the class which has been abortively ruling the country since its 
birth in 1971.This is the "tradition" of the class "...that has never made decolonization one of their central tasks a tradition that has long been known for its ideological slavery, a tradition that continues to equate democracy with 'free and fair elections' instead of taking democracy as the equality of rights and opportunities, a tradition that remains tied to and even dictated by corporate interests and US imperialism, and in short, a tradition that has reached its creative-end" (Husain, 2009,1 ). Long ago, this fate of states has been predicted by Sartre that bourgeoise take- over of the states is fated to be parasitic on imperialism if national revolution is not socialist in nature (Fanon,1961:10). So, the parasitic nature of this colonially wombed middle class has given birth to two "passive revolutions" (Khan:2007) one in 1947 and another in 1971. Serajul Islam Choudhury puts it thus: "The state has changed in size and name but not in character, indicating that relationships within society have remained basically as they were before (Choudhury, 2002:1st Flap).

We would like to argue that the absence of strong decolonizing and resistive discourses has led to fragile and colonial type of states that we are experiencing now. In this marked absence of decolonizing culture, we would like to briefly see the role of English language and literature. Here, we think, Pennycook (1998) has summarized the colonial language policy very well:

Colonial language policies can be seen as constructed between four poles: first, 'the position of colonies within a capitalist empire and the need to produce docile and compliant workers and consumers to fuel capitalist expansion; second, local contingencies of class ,ethnicity, race and economic condition that dictated the distinctive development of each colony; third, the discourses of Anglicism and liberalism with their insistence on the European need to bring civilization to the world; and fourth, the discourses of Orientalism with their insistence on exotic histories, traditions and nations in decline. From amid these often competing demands emerged colonial language policies of many different hues that worked generally to bolster the economic and political position of Britain but which also operated along particular ideological position that gained sway in particular contexts.(68) 
To see, how these policies have worked, we would like to give two examples: One from traditional practice of language and another from traditional practice of literary criticism. From our experience, we have seen that many applications in our culture start with, "I beg to state that..." and almost invariably end with, "Your most obedient...".Thus; language has been, even post-colonially, an agency to indicate a subordinating position. Also, in the traditional (colonized) practice of literary criticism until recently, we have often uncritically praised and over-praised many of the canonical figures who happened to be colonial propagandists. They advocated empire's freedom that denied freedom to many turning them into 'wretched of the earth.' (Hussain: 2007)

Terry Eagleton in "Literary Theory" (1983) has explained that English Departments have not been Departments of Literature only because of this monopolization of the British nationalism and its cultural hegemony (qtd in Norton:2089). In line with this view, Ngugi in "Literature and society"(1973), argues that in the dynamics of neocolonialism "Cultural imperialism" contributes notably in the fields of language, literature and education. Based on these realizations out of decolonizing necessity the views expressed in "On the Abolition of The English Department"(1968) are provocative, exciting and of course, challenging. This is a quote from the paper:

The English Department has had a long history at this College and has built up a strong syllabus which by its study of the historic continuity of a single culture throughout the period of emergence of the modern west, makes it an important companion to History and to Philosophy and Religious Studies. However, it is bound to become less 'Briitish', more open to other writing in English (American, Caribbean, African, Commonwealth) and also to continental writing, for comparative purposes. (2093)

Echoing the sentiment, "We suggest rejecting the primacy of" English literature and culture to set our own goals. Here suggest a few initial points for our English language and Literature Departments:

(a) "For comparative purposes" as is also suggested by Aijaz Ahmed as "Comparatism" (Ahmed,199:52) we could introduce as many literatures as possible from different cultures with special priority for native literature which might include sophisticated translated works of 
indigenous cultures . Along with making us conscious about ourselves, it will save us from being marginalized into "fixed literary patterns". This will also provide scope for us to experience "contrapuntal reading" which has been convincingly argued for by Edward Said. (Qtd in Islam, 2004-5:179)

(b) In principle, here we fully agree with the analysis and suggestions made by Fakrul Alam. In his essay, "Using Postcolonial Literature in ELT", published: "Imperial Entanglement and Literature in English". Echoing him, we would like to emphasize two points:

(i) From the decolonizing perspective and to resist linguistic imperialism, " it (language) must also make an attempt to make our students grasp our history and sensitize us to the fact that language can be a means of resistance and opposition" (Alam,2007:384). Otherwise, it will run the risk of producing uncritical unimaginative, submissive and mechanistic language operators to serve Macaulay's colonial interests postcolonially. Since this is the practice Fakrul Alam appropriately opines, “...English for Today represents an opportunity wasted...”.

(ii) We can increasingly use our own experience and expertise to devise and design language syllabi at all levels reducing our subordination to foreign experts.

In conclusion, agreeing with Niaz Zaman's essay, we can say that "Caliban's children" can use the language not only to resist but also "revel in the immense possibilities of language" to tame it to suit their purpose. A similar view is also voiced by Liyong, "we will not have to stick to Queen's English [;] ...we have to tame the shrew and naturalize her..." (qtd in Norton:2091). If we fail to do so, we will continue to suffer from the anxieties of uprootedness and alienation like The English Teacher by R K Narayan: “...This education has reduced us to a nation of morons : we were strangers to our own culture and camp followers of another culture, feeding on leavings and garbage ....what about our own roots ?'(qtd in O'Reilly ). Perhaps, these are the anxieties suffered by so many of us but confessed by so few. To reduce these anxieties and tensions we have to be more and more "organic" in Gramscian sense of the term. Definitely, our task will be more complex; therefore, it will be more interesting, challenging and exciting.

\section{Works Cited}


Achebe. Chinua; The African writer and The English language: A Worldview Critical Companion.Ed .Tapan Basu .Delhi: Book land Publishing Co 2003.

Ahmed. Aijaz; The Future of English Studies is South Asia: Colonial and Post colonial Encounters .Eds .Niaz Zaman, Firdous Azim and Shawkat Husain Dhaka:The University press limited,1999.

Alam. Fakrul; Imperial Entanglements and Literature in English. Dhaka: Writers.ink, 2007.

Behdad. Ali; ON Globalization Again: Post colonial studies and Beyond Eds. Ania Loomba,Suvir Kaul, Matti Bunzl, Antoinette, Burton, Jed Esty, New Dehi: permanent bluck,2008.

Choudhury. S. I; Middle class and The social Revolution in Bengal :An Incomplete Agenda Dhaka: The University Press Limited ,2002.

Fanon. Frantz.; The wretched of the Earth. Trans. Constance Farrington. reprint. London: Penguin Books, 1963.

Hinders. Barry. Not at Home in the Empire social identities Volume 7, Number 3, 2001

Hussain. Azfar, Of Disparities and Discrepancies: Micronarrative sequence; eighteen. 20 April, 2007. http://www.newagebd.com/2007/apr/20/liti.html.

---- Democratization, decolonization and the dialectics of culture. http://www.newagebd.com/2007/ th special anniversary.

Islam. Shahidul M; R Eading Western Literature after Said: People on the Periphery. Panini: NSU Studies in Language and Literature, Vol.3:2004-2005

Khan. Salimullah; Adhunik O Uttaradhunik, [Bangla] [Adomboma], Dhaka, Agami Prokasoni, 2009.

---Allahar Badshahi, [Bangla] [Dorothy Jeller Kobita], Dhaka: Somabesh, 1998.

---- Behat Biplob 1971[Bangla], Dhaka: Anniswa,2007.

Ngugi, Liyong and Owuor-Anyumba: "On the Abolition of the English Department"(1968) The Norton Anthology of Theory and Criticism, , First Edition. Ed. Leitch, Vincent B...New York and London: W.W. Norton and Company.

Parenti Michael: Against Empire. http://www.michaelparenti.org/Imperialism 101. html

Pennycook, Alastair. English and the discourses of Colonialism. London: Routledge, 1998.

Roy Arundhati. Listening to Grasshoppers ( field notes on democracy). New Delhi: PENGUIN BOOKS, 2009.

Zaman, Niaz. Caliban's Children: Salman Rusdie and Shash Tharoor: Colonial and Post colonial Encounters .Eds. Niaz Zaman, Firdous Azim and Shawkat Husain Dhaka: The University press limited, 1999. 